\title{
Architektura nowego stylu zakopiańskiego. Odrodzenie stylowe czy popkulturowy kicz i historyczne niezrozumienie?
}

DOI: https://doi.org/10.21697/an.9377

ANNA WIŚNICKA

WYDZIAL NAUK HUMANISTYCZNYCH UKSW

ORCID 0000-0002-6821-529X

Styl zakopiański należy do najbardziej twórczych i dystynktywnych dokonań polskiej architektury rezonujących na obecne tendencje architektoniczne oraz funkcjonujących w globalnie rozumianej popkultu$\mathrm{rze}^{1}$. Inspirował rzesze artystów od momentu swego ukonstytuowania na przełomie XX w., a jego artystyczne echa pobrzmiewają do dziś, będąc świadectwem wyjątkowej roli, jaką pełnił na przestrzeni ostatnich stu lat. Szczególne miejsce w kontekście artystycznego dialogu zajmuje architektura najnowsza, która, pomimo wielu rewolucji stylowych, by wspomnieć tę najbardziej radykalną, jaką jawił się modernizm, wciąż chętnie nawiązuje na gruncie rodzimym do modelu klasycznego stylu zakopiańskiego. Wychodząc od założeń Stanisława Witkiewicza oraz teorii architektonicznego odrodzenia i neowernakularyzmu, tekst przybliża i analizuje przykłady tzw. nowego stylu zakopiańskiego. Jest próbą odpowiedzi na pojawiające się pytania: czy zjawisko

1 M. Murzyn, Wpływ turystyki masowej na dziedzictwo Zakopanego, „Turystyka Kulturowa”, 2015, nr 10, s. 72-85. powrotu tendencji estetyki witkiewiczowskiej można uznać za jej odrodzenie, czy jedynie za nieudolne kopiowanie? Czy w dobie dominacji popkulturowego kiczu możliwa jest twórcza, pozbawiona sentymentalizmu reinterpretacja stylu zakopiańskiego, która mieści w sobie zrozumienie idei jego twórcy? Czy wreszcie można prowadzić dialog z historyczną spuścizną, który będzie jej organiczną ewolucją, a nie bezrefleksyjnym kopiowaniem najbardziej emblematycznych detali?

Chcąc przyjrzeć się genezie i estetyce nowego stylu zakopiańskiego, należy rozpocząć od zdefiniowania jego zakresu pojęciowego. Choć nie jest to hasło semantycznie zakorzenione w terminologii historii sztuki, architektury czy dizajnu, pojawia się epizodycznie w przestrzeni ich dyskursu oraz przenika do sfery popkultury, określając cały wachlarz zjawisk artystycznych o bardzo odmiennej naturze. Podstawą do podniesienia kwestii fenomenu, jakim jest swoiste odrodzenie się pewnych tradycji stylowych obecnych w obszarze zakopiańskim przełomu XX w., był popularnonaukowy reportaż autorstwa Marcina Czechowicza, opublikowany na łamach pisma „Murator”.

2 Zob. M. Czechowicz, Nowy styl zakopiański, „Murator” 
Wychodząc od 120. rocznicy powstania Willi Pod Jedlami Stanisława Witkiewicza, autor przywołuje reprezentatywne przykłady architektury powstające w Zakopanem, określając je wspólnym mianem nowego stylu zakopiańskiego. Już na wstępie rozważań warto zauważyć, iż podstawą tej kompilacji, poza luźnymi odwołaniami estetycznymi, stała się kategoria lokatywna, która zawęża znacząco obszar przytaczanych budowli do Zakopanego i jego okolic. Ponadto większość zaprezentowanych przykładów została wzniesiona po roku 2000, co każe przypuszczać, iż stylem tym w popularnej narracji określa się architekturę najnowszą, której cezurą czasową jest XXI w.

Na potrzeby rozważań o naturze nowego stylu zakopiańskiego oraz jego osadzeniu w tradycji popkultury, oscylującej chwilami na granicy kiczu, utrzymane zostaną ramy czasowe kwalifikujące budynki powstałe w obecnym stuleciu. Kwestią, która winna jednak ulec zmianie, jest geograficzna klasyfikacja budowli. Nie jest ona tu reprezentatywnym czynnikiem lokującym obiekty w ramach kategorii stylowych. Historycznie świadczy o tym choćby środowisko drewnianej architektury rezydencjonalnej Nałęczowa, która niewątpliwie znajduje swoje źródła w dokonaniach twórczych Witkiewicza seniora ${ }^{3}$, a trudno byłoby sytuować ją jako geograficznie bliską oryginałowi. Biorąc pod uwagę względy historyczne, mechanizmy transponowania stylów dawnych we współczesnej architekturze oraz postępującą globalizację, która skutkuje pojawianiem się neotendencji

wydanie online 30 XI 2017, https://architektura. muratorplus.pl/krytyka/nowy-styl-zakopianski-fotoreportaz-marcina-czechowicza_8159.html [dostęp 24 IX 2020].

3 L. Gazda, M. Górski, K. Skiba, Analiza możliwości adaptacji drewnianego obiektu rekreacyjnego w funkcjonalny obiekt mieszkalny z zachowaniem rozwiązań i technologii wernakularnych, „Budownictwo i Architektura", t. 14, 2015, nr 4, s. 29-42. stylowych w oddaleniu od miejsca ich pierwotnego powstania, selektywny wybór materiału nie ograniczy się do terytorium Zakopanego. Analizie poddane zostaną wybrane przykłady prac powstałych na terenie województwa małopolskiego po $2000 \mathrm{r}^{4}$, które noszą znamiona inspiracji klasycznym modelem stylu zakopiańskiego.

Bardzo istotną kwestią, która pozwoli na obiektywną selekcję, klasyfikację i analizę przykładów nowego stylu zakopiańskiego, jest sprecyzowanie sposobu rozumienia pojęcia „neostylu” lub, co stosowane jest znacznie częściej w globalnym dyskursie, pojęcia „architektonicznego odrodzenia”- „rewiwalizmu" (architectural revival). Termin neostyl stosowany jest dla określenia twórczego wykorzystania wiodących tendencji stylowych historycznie ukonstytuowanego zjawiska artystycznego. Odrodzenie stylowe zakłada natomiast odniesienie się do przeszłości, będące jej naturalną ewolucją, a więc noszące znamiona poprawy wartości zjawiska, którego dotyczy. Badania przeprowadzone w $2018 \mathrm{r}$. w Eidhoven (Robert Cuijpers, Myrthe Eummelen i in.) dowodzą, że ewolucja ta może być rozumiana na wiele sposobów - jako naprawa historycznej spuścizny architektonicznej, kopiowanie dawnych wzorców, utylizacja elementów dawnej architektury, takich jak spolia, eklektyzm i nowoczesne połączenie elementów stylowych różnych epok, oraz popularyzacja konkretnego zjawiska, jakim jest estetyczny powrót do przeszłościs

\footnotetext{
4 Odejście od pierwotnie przyjętego kryterium ograniczającego zakres przytaczanych przykładów jedynie do granic Zakopanego nie świadczy bynajmniej, że omawiany typ budowli staje się ogólnopolskim trendem architektonicznym.

5 R.F.A. Cuijpers, M.K. Eummelen, B.H.J. van Groesen, J.W.M. Kohlmann, B.R.J. van der Vleugel, M. Zondag, Redefining revival: a systematic review on vernacular and non-place-bound revival, wystąpienie podczas konferencji „Living Cities 5 At: Eindhoven, Holandia”, tekst oraz wyniki badań udostępnione za pośrednictwem ResearchGate, www.researchgate.net/ publication/326462248 [dostęp 4 X 2020].
} 
Rozważając rozległość sposobów interpretacji odrodzenia się architektury epok minionych, powinno się wyodrębnić jeszcze dwie ogólne kategorie reaktywacji architektonicznych wzorców przeszłości. Pierwszą z nich jest odrodzenie niepowiązane ściśle z miejscem powstania pierwowzoru (non-place-bound revival), drugą - odrodzenie wernakularne (vernacular revival), w przypadku którego kontekst geograficzno-historyczny stanowi wartość dodaną. Druga kategoria wymaga doprecyzowania, co słusznie podkreśla zespół Cuijpersa, dzieląc ją na dwie podstawowe podgrupy rodzimą architekturę wernakularną (,odtwarzanie budynków i elementów budowlanych należących do konkretnej kultury i regionu, w którym się znajdują") oraz tzw. zaimportowaną architekturę wernakularną („nakładanie się elementów rodzimej architektury w obszarze geograficznym i społeczno-kulturowym różniącym się od lokalizacji, w której ta architektura i elementy są pierwotnie zakorzenione") ${ }^{6}$. Jest to ważne kryterium pozwalające przeanalizować, czy przykłady budowli powstających w bezpośrednim sąsiedztwie pierwowzoru wykazują inne cechy stylowe niż te, które dzieli od Zakopanego znaczny dystans.

Podniesienie kwestii lokalności i unikatowości architektury jest równie istotne dla podjętego tematu. Terminy wernakularyzm i neowernakularyzm, które ściśle powiązane są zarówno z neostylem, jak i odrodzeniem architektonicznym, wymagają w tym kontekście pewnego wyjaśnienia oraz doprecyzowania. Pomimo łacińskiego źródłosłowu, geneza przymiotnika wernakularny w odniesieniu do architektury w literaturze przedmiotu sięga drugiej połowy XIX w.7, zyskując na popularności dopiero

6 R.F.A. Cuijpers i in., dz. cyt., s. 13.

7 G.G. Scott, Remarks on Secular \& Domestic Architecture, Present \& Future, London 1858, reprint Charleston 2012. w piśmiennictwie XX w., kiedy dał się zauważyć gwałtowny wzrost zainteresowania etnografią rdzennych kultur oraz ich działalnością artystycznąi. Termin architektura wernakularna, w najszerszym słownikowym ujęciu, oznacza „architekturę zakorzenioną w tradycji lokalnej, tworzoną przez miejscowych, anonimowych budowniczych i rzemieślników, bez przygotowania akademickiego". Lokalny i utylitarny charakter architektury wernakularnej podkreśla również Grzegorz Rytel, odwołując się do jej podstawowych funkcji, pisząc, że jest ona „codzienna, zaspokajająca najważniejsze potrzeby, doskonalona z pokolenia na pokolenie w rozpoznawanych przez użytkowników wzorach" ${ }^{10}$. Bardzo mocno zaakcentowane zostały aspekty jej rozpoznawalności na konkretnym obszarze kulturowym, utożsamiając ją tym samym z elementami będącymi składowymi kultury lokalnej czy regionalnej ${ }^{11}$. Jest to szczególnie istotne przy próbie spojrzenia na architekturę w kontekście szerszym niż geograficzne występowanie pierwowzoru. Liczne sposoby definiowania wernakularyzmu odnoszą się bowiem bardzo mocno do kwestii usytuowania powstających obiektów. Józef Tarnowski zaproponował

\footnotetext{
8 Należy w tym miejscu zasygnalizować, iż na gruncie etnograficznym pojawiają się propozycje innego spojrzenia na kwestie wernakularyzmu i neowernakularyzmu. D. Angutek, Folkloryzm i postfolkloryzm jako etnologiczna alternatywa terminologiczna obok wernakularyzmu i neowernakularyzmu, w: Wernakularyzm i neowernakularyzm w sztuce, literaturze i myśli o sztuce, red. E. Kal, Słupsk 2019, s. 57-67.

9 Architektura wernakularna, w: Encyklopedia PWN, online: www.encyklopedia.pwn.pl/haslo/wernakularna-architektura;3994881.html [dostęp 4 X 2020].

10 G. Rytel, Wernakularna, czyli jaka? Uwagi semantyczne na marginesie tematu konferencji, „Budownictwo i Architektura", t. 14, 2015, nr 3, s. 143-149.

11 Zob. I. Bukowska-Floreńska, Kultury regionalne w społeczeństwach nowoczesnych. Problemy i propozycje badawcze, „Studia Etnologiczne i Antropologiczne”, t. 2, 1999, s. 15-22.
} 
regulację siatki pojęciowej ${ }^{12}$, która poszerza spektrum rozumienia kwestii regionalizmu oraz ludowości architektury. Przywołany zakres obejmuje siedem pojęć, które wyczerpująco definiują omawiane zjawisko i jego liczne alternacje, a są nimi: wernakularyzm prymarny, neowernakularyzm prymarny, wernakularyzm sekundarny, neowernakularyzm sekundarny, wernakularyzm tercjalny (postmodernistyczny), neowernakularyzm rewiwalistyczny oraz neowernakularyzm imitacyjny. Podążając za przyjętą wcześniej typologią, definicja wernakularyzmu prymarnego jest tożsama $\mathrm{z}$ aktualnym dyskursem uznanym przez historyków architektury i opiera się o regionalnie występujące przykłady budownictwa tworzonego przez lud. Podobnie utrzymane zostało hasło neowernakularyzmu prymarnego, które określa budowle nawiązujące do form architektury wernakularnej, tworzone przez profesjonalistów. Wernakularyzm sekundarny obejmuje dzieła twórców ludowych, współpracujących wcześniej z profesjonalistami, które wzorowane są na neowernakularyzmie prymarnym. Neowernakularyzm sekundarny jest rozumiany jako artystyczna parafraza neowernakularyzmu prymarnego. Neowernakularyzm tercjalny obejmuje budowle modernizujące, nawiązujące w pewnych elementach do obiektów wernakularyzmu sekundarnego. Na końcu autor wyodrębnia dwie dodatkowe definicje wernakularyzm rewiwalistyczny będący architekturą współczesną czerpiącą z wzorców wernakularyzmu prymarnego oraz wernakularyzm imitacyjny, którego przykłady oparte są na wizualnej imitacji pierwowzoru, z pominięciem prawideł struktury i materiałów. Przytoczone przykłady dowodzą, że istniejąca dywersyfikacja form architektonicznych nawiązujących w jakimś

12 J. Tarnowski, Wernakularyzm i neowernakularyzm: zamiast wstępu, w: Wernakularyzm i neowernakularyzm..., dz. cyt., s. 9-34. stopniu do omawianego stylu zakopiańskiego, wymaga zastosowania terminologii wykraczającej poza definicję wernakularyzmu oraz neowernakularyzmu. Wyjaśnienie warstwy semantycznej staje się tym bardziej istotne, gdy do materiału komparatystycznego zalicza się przykłady architektury, której proweniencja nie spełnia geograficznych kryteriów lokalności. W odniesieniu zarówno do przytoczonej propozycji definiowania rewiwalizmu wernakularnego, jak i mnogości odmian neowernakularyzmu możliwa staje próba odpowiedzi na pytanie, w jakim stopniu przykłady budownictwa inspirowanego pracami Stanisława Witkiewicza mogą świadczyć o rewiwalizmie stylu zakopiańskiego.

By móc dokonać analizy wyselekcjonowanego materiału z obszaru tzw. nowego stylu zakopiańskiego, należy zwięźle przywołać kluczowe wartości architektury klasycznego stylu zakopiańskiego, które zdefiniowały jego powszechne rozumienie dziś. Model architektury wypracowany przez Stanisława Witkiewicza wywodzi się z budownictwa miejscowego, którego emblematycznym przykładem była chata góralska ${ }^{13}$. Jej elementy, w różnym kształcie, powielane były we wszystkich projektach stylu zakopiańskiego. Ów skromny, lokalny pierwowzór, tworzony przez miejscowych rzemieślników, stał się podwaliną estetyki, która nierozerwalnie kojarzona jest z Zakopanem i jego okolicami. Stanisław Witkiewicz podkreślał wkład endemicznej szkoły budowlanej oraz wagę artyzmu niewykształconych rzemieślników, akcentując

13 Góralska chałupa, przytaczana tu jako model architektoniczny leżący u podstaw stylu zakopiańskiego, stanowi element, o którym pisał Witkiewicz. Należy podkreślić, iż nie jest jedynym źródłem architektonicznych inspiracji. Zob. m.in. K. Kwiatkowski, Konfrontacja stylów narodowych imperiów ze stylami narodowymi terytoriów zależnych, „Przestrzeń, Urbanistyka, Architektura", 2020, nr 1, s. 67-76; oraz J. Tarnowski, Styl alpejski w środkowej Europie i polska kontrakcja wobec niego - styl zakopiański, „Estetyka i Krytyka”, 2012, nr 25 (2), s. 231-246. 
ich rolę w kultywowaniu tradycji - ,nade wszystko te właśnie Wojtki i Maćki, którzy ten skarb kultury dawnej przechowali w najbardziej rozwiniętej formie i w stanie żywym i którzy mieli w sobie niezrównane przymioty najwytworniejszych rzemieślników i artystów" ${ }^{14}$. Równie istotnym elementem nowo powstającego stylu była lokalizacja obiektów, które „oparte na motywach budownictwa miejscowego, były przykładem ścisłego związku pomiędzy koncepcją architektoniczną, a środowiskiem naturalnym, sytuowane $\mathrm{z}$ reguły w atrakcyjnych miejscach o dużych walorach krajobrazowych" ${ }^{15}$. Należy pamiętać, że styl zakopiański objął swoim zasięgiem nie tylko architekturę, ale również wzornictwo czy modę, co świadczy o jego ogromnej sile oddziaływania. Popularyzacja elementów kultury podtatrzańskiej oraz ich recepcja miały wpływ na tworzenie tego, co określane bywa duchem epoki ${ }^{16}$. Przede wszystkim jednak styl zakopiański był ideologią osadzoną w kontekście państwa pod zaborami, a więc czynnikiem unifikującym i kulturotwórczym, co miało niepoślednie znaczenie dla jego rozwoju ${ }^{17}$.

Odnosząc się do architektury krajobrazu, tak ważnej w określaniu kategorii stylu zakopiańskiego, a realizowanej przez nowy styl zakopiański w sposób budzący wątpliwości natury estetycznej, należy przywołać przykład zabudowy na Pardałówce. Ogromne, położone w bliskiej odległości od siebie osiedla mieszkalne pozbawione są dystansu niezbędnego do

14 S. Witkiewicz, Wybór pism estetycznych, red. J. Tarnowski, Kraków 2009, s. 263.

15 T. Biernot, Budynki witkiewiczowskie w Zakopanem. Materiały z badań inwentaryzacyjno-studialnych obiektów historycznych, Gliwice 2010, s. 35.

16 A.D. Sznapik, Tatrzańska Arkadia. Zakopane jako ośrodek artystyczno-intelektualny od około 1880 do 1914 roku, Warszawa 2009, s. 226-231.

17 A.M. Pycka, Kreacje i poglądy Stanisława Witkiewicza na tle głosów epoki, Kraków 2010, s. 166. zaakcentowania walorów krajobrazowych, o których była mowa. Na poziomie społeczności lokalnej, wdrożone plany urbanistyczne również nie spotkały się z powszechną aprobatą. Architekt Andrzej Bachleda Curuś bardzo dobitnie opisał stan obecnej zabudowy Pardałówki - „najpierw stały tam domy jednorodzinne, potem pojawiły się bliźniaki, a pod rządami nowej ustawy - pięciokondygnacyjne apartamentowce, które utworzyły gęsto i chaotycznie zabudowane niby-góralskie blokowisko. Jego elewacje porażają jaskrawymi, wściekłymi barwami"18. Konstatując obecny stan rzeczy: wydaje się, że plany zagospodarowania przestrzennego nie definiują wytycznych, które pozwoliłyby na spójną zabudowę, utrzymaną w tradycji lokalnej. Jedynym elementem wspólnym jest dach, który w jakimś stopniu nawiązuje do formy półszczytowej. Jako że to właśnie on w popularnym rozumieniu stał się wyznacznikiem stylu zakopiańskiego, architektura Pardałówki wykorzystała ten właśnie element do zaakcentowania lokalności nowego budownictwa. Przykładem, który bardzo dobrze ilustruje to podejście jest Hotel Paryski zaprojektowany przez Marię Stępniewską-Szulc (il. 1). Budynek składa się z połączonych ze sobą segmentów pięciokondygnacyjnych bloków mieszkalnych, które konstrukcyjnie nie mają nic wspólnego z architekturą stylu zakopiańskiego. Niezrozumienie spuścizny historycznej oraz konieczność podporządkowania się współczesnym prawom rynku budowlanego skutkują coraz liczniejszą grupą obiektów, które pretendują do miana spadkobierców lokalnej szkoły budowlanej, całkowicie ignorując jej prawidła. W związku z brakiem regulacji prawnych oraz wzorników, które mogłyby stanowić wytyczne dla

\footnotetext{
18 Cyt. za [b.a.], Ostał wam się ino spadzisty dach, „Rzeczpospolita”, 10 III 2008, wyd. online: www.rp.pl/ artykul/104921-Ostal-wam-sie-ino-spadzisty-dach. html [dostęp 20 X 2020].
} 


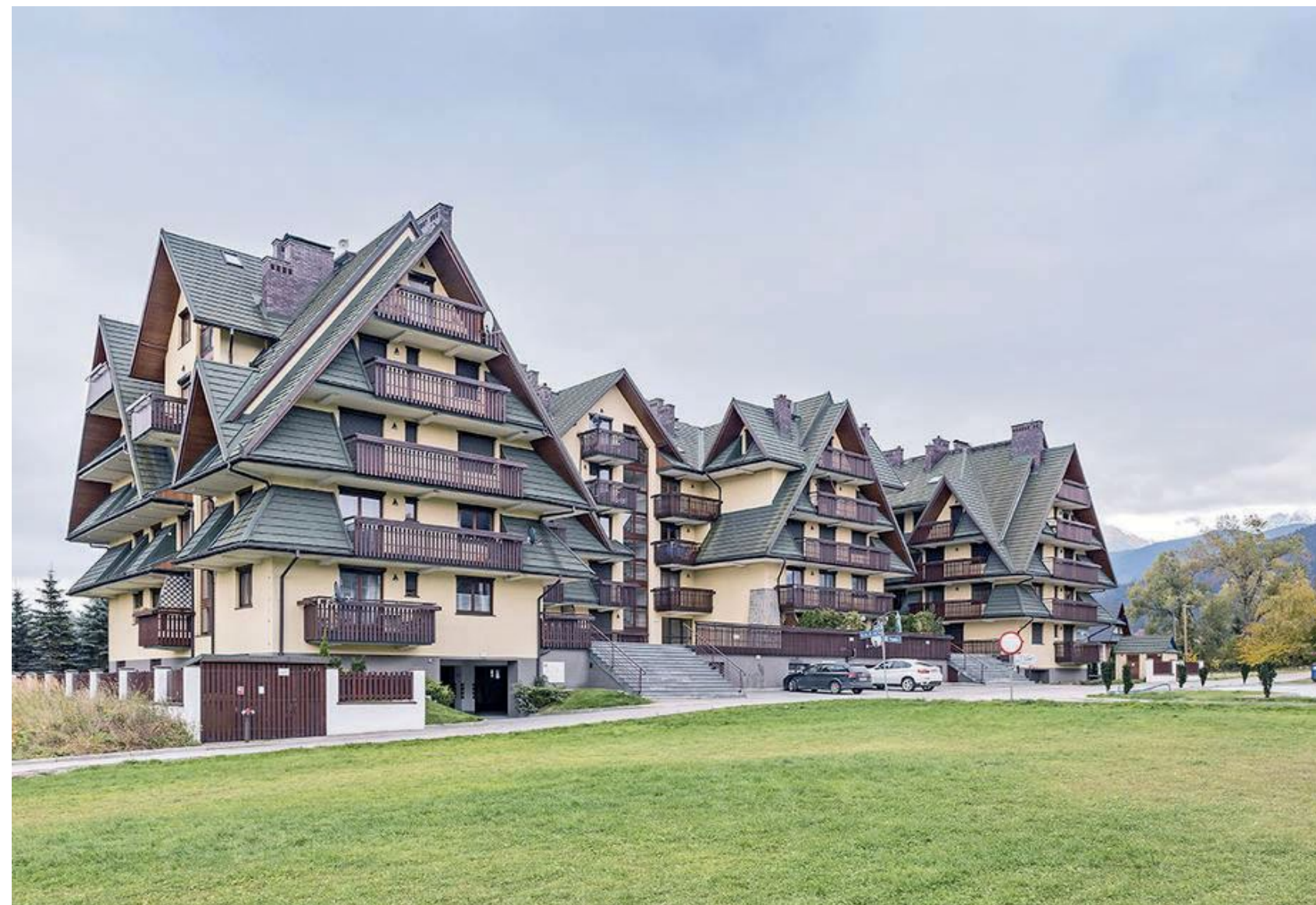

1. Hotel, arch. Maria Stępniewska-Szulc.

Fot. wg: Marcin Czechowicz, w: architektura.muratorplus. $\mathrm{pl} /$ krytyka/nowy-styl-zakopianski-fotoreportaz-marcinaczechowicza_8159.html [dostęp 20 X 2020]

nowopowstających obiektów, na terenach Zakopanego i okolic zaobserwować można narodziny pewnego stylowego kuriozum, które staje się coraz powszechniejsze.

Materiały, mające symbiotycznie współgrać z otaczającą przyrodą, zastąpiono żelazobetonem, a ornamentyka i rękodzieło ustąpiły miejsca masowo produkowanym przedmiotom. W tym ujęciu tradycje klasyki szkoły zakopiańskiej przestały istnieć, a architektura Pardałówki niezbicie dowodzi powstania nowego stylu, który jednakże trudno w jakimkolwiek stopniu utożsamiać $\mathrm{z}$ dziedzictwem Witkiewicza.

Popularyzator stylu zakopiańskiego wychodził z założenia, iż budownictwo „opiera się na wiadomych, określonych i stałych zasadach, od których nie ma zboczeń albo jeżeli - to styl ten ginie, zupełnie tak samo, jak każdy inny. Jego rozwój jest stosowaniem do budowli bardziej złożonego typu tych niezmiennych, ujętych w ściśle określone zasady pierwiastków formy. Chałupa składa się z dwóch, najwyżej z trzech izb, komory i sieni, możemy zbudować zamek o stu pokojach i stu wieżach albo katedrę wielką jak katedra kolońska, jeżeli tylko zastosujemy wymiary i konstrukcje polskiego budownictwa ludowego - otrzymamy gmach w stylu zakopiańskim. Nie inaczej się też dzieje z każdym innym stylem"19. Przyglądając się rozwojowi budownictwa infrastruktury turystycznej, łatwo dostrzec całkowitą ignorancję względem krajobrazu architektonicznego, który historycznie ukształtował Zakopane. Powstające

19 S. Witkiewicz, dz. cyt., s. 269. 
obecnie „nowozakopiańskie” hotele i pensjonaty $^{20}$ traktują dorobek Witkiewicza jako wizualne odwołanie, pozbawione refleksji estetycznej. Podyktowane jest to w dużej mierze względami ekonomicznymi oraz brakiem obostrzeń w kwestii planowania przestrzennego. Sytuację może zmienić jedynie spójny model

20 W kontekście architektury hoteli warto nadmienić, iż powstają również realizacje bardzo nowoczesne, które w sposób twórczy wykorzystują lokalne materiały i na poziomie detali prowadzą estetyczny dialog z przeszłością, czego przykładem jest budynek Bachleda Club Residence zaprojektowany przez biuro projektowe Karpiel-Steindel, www.karpielsteindel. eu/projekt/bachleda-club-residence [dostęp $20 \mathrm{X}$ 2020]. zagospodarowania przestrzennego, który dokona krytycznej analizy architektury historycznej i wypracuje rozwiązania estetyczne, mogące $\mathrm{z}$ nią integralnie koegzystować ${ }^{21}$.

Najpopularniejszym rodzajem budowli odwołującej się do klasyki

21 Znaczne zasługi na polu szerzenia świadomości historycznej ma Krakowska Szkoła Projektowania Architektonicznego wraz z prof. Andrzejem Skoczkiem oraz prof. Stefanem Żychoniem. Więcej na temat możliwości urbanistycznych oraz historii szkoły krakowskiej zob. D. Kronowski, Wpływ architektury neoregionalnej i nowoczesnej na kształtowanie myśli krakowskiej szkoły projektowania architektonicznego, „Teka Komisji Urbanistyki i Architektury O/PAN W Krakowie", t. 42, 2014, s. 85-129.

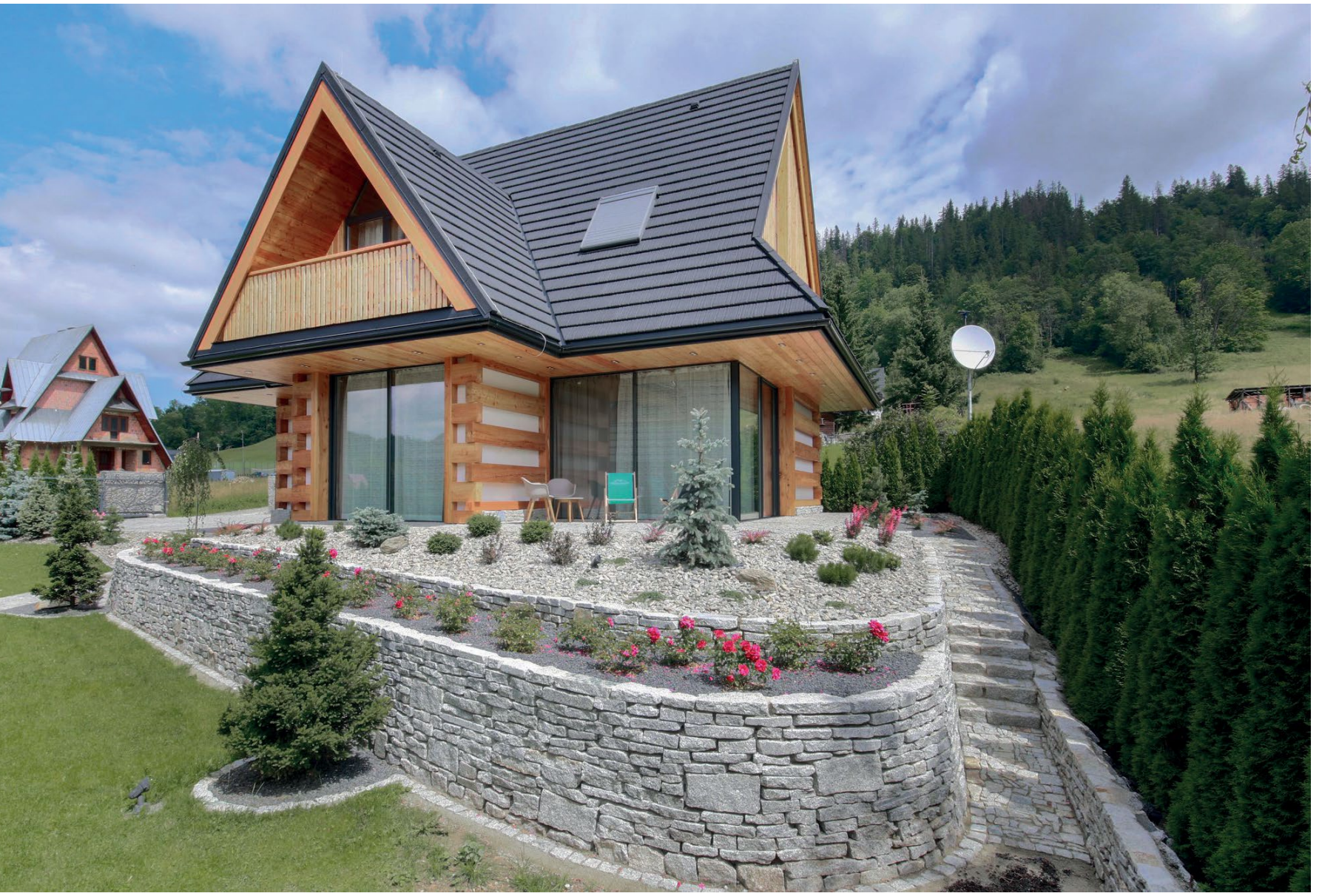

2. Wioska Jagny, Biuro architektoniczne Karpiel i Steindel.

Fot. wioskajagny.pl [dostęp $20 \mathrm{X}$ 2020] 
witkiewiczowskiej są domy mieszkalne. Mogłoby się wydawać, że to właśnie one mają potencjał, by najpełniej realizować założenia stylu zakopiańskiego, który wywodzi się wprost $\mathrm{z}$ analizy i reinterpretacji podhalańskiej chałupy. Za przykłady powstałe po roku 2000 mogą posłużyć domki pod Giewontem ${ }^{22}$, dom Jana Karpiela na Gubałówce czy kompleks domków w wiosce Jagny w Poroninie ${ }^{23}$ (il. 2). Cechą wspólną wszystkich realizacji jest nawiązanie do lokalnej architektury, co jednak nie jest tożsame z inspiracjami stylem zakopiańskim. Liczne przykłady popkulturowej interpretacji dawnych wzorów zdają się tworzyć obecnie uniwersum stylowe, które wywiera na architektów silniejszy wpływ niż estetyka Witkiewicza głównie ze względu na znaczne uproszczenie w stosunku do pierwowzoru oraz powiązane z nim czynniki ekonomiczne. Wszystkie przykłady budowli mieszkalnych w nowym stylu zakopiańskim łączy odwołanie się do formy dachu znanego z budowli w klasycznym stylu zakopiańskim, lecz jedynie w warstwie wizualnej, nie w odniesieniu do użytych materiałów. Rzadkością są również prace snycerskie, które stanowiłyby dekorację w relacji z architekturą oraz wnętrzem, co było cechą charakterystyczną willi przełomu XX w. Już na poziomie estetycznym zauważa się odejście od pryncypiów stylu, o których pisał Witkiewicz, podkreślając konieczność zachowania konsekwencji, gdyż „budownictwo to ma swoje szczególne, silnie ugruntowane cechy, które je różnią od budowli innych typów i które nie mogą być niczym innym, jak tymi najistotniejszymi pierwiastkami formy, stanowiącymi o istnieniu każdego stylu. Pierwiastki te muszą zatem być ujęte w pewne stałe i trwałe normy wymiarów i konstrukcji, które każdego, chcącego

22 www.domki-pod-giewontem.pl [dostęp 20 X 2020]. 23 www.wioskajagny.pl [dostęp 20 X 2020]. w tym stylu budować, z góry już same zmuszają do zachowania jego charakteru, przez proste tych norm zastosowanie" ${ }^{24}$. Największa różnica jest jednak zauważalna w konstrukcji. Architektura drewniana, czerpiąca z tradycji chaty, o konstrukcji zrębowej, ustawiona na kamiennej podmurówce, została zastąpiona murowanymi ścianami, które jedynie ozdabia się w stylu nawiązującym do zakopiańszczyzny Witkiewicza. Chętnie stosowany kamień elewacyjny oraz dekoracyjne okładziny z prostych desek modrzewiowych to jedyne reminiscencje lokalnego budownictwa, z którego słynęło niegdyś Zakopane. Powstające obecnie realizacje $\mathrm{z}$ drewna stanowią zdecydowaną mniejszość, czego przykładem są wspomniane domki pod Giewontem.

Wśród przykładów czerpiących bardzo powierzchowne inspiracje ze stylu zakopiańskiego liczną grupę stanowią budowle, które swoistą geometryzację i góralską ornamentykę zastąpiły organiczną formą, będącą raczej reminiscencją szeroko pojętego stylu Art nouveau niż powrotem do estetyki Witkiewicza. Propagatorem owej hybrydy estetycznej jest Sebastian Pitoń, który swoje projekty określa mianem drewnianej architektury organicznej. W tym duchu utrzymany jest dom na polanie Sywar$\mathrm{na}^{25}$. Dom o asymetrycznej formie ma elewację z drewna i kamienia, co nawiązuje do materiałów stylu zakopiańskiego (il. 3). Na tym jednak kończą się podobieństwa, bowiem wielospadowy dach o falistym kształcie oraz ornamentalno-floralne obramienie okien zdają się czerpać raczej z krynicy inspiracji spuścizną Gaudiego ${ }^{26}$ niźli rodzimych form architektury podhalańskiej. Zbyt daleko idące zmiany nie

24 S. Witkiewicz, dz. cyt., s. 269.

25 Dom na polanie Sywarna, ul. Kościelisko Sywarne 44.

26 C. Kent, D. Prindle, Park Güell, New York 1993, s. 61-84. 


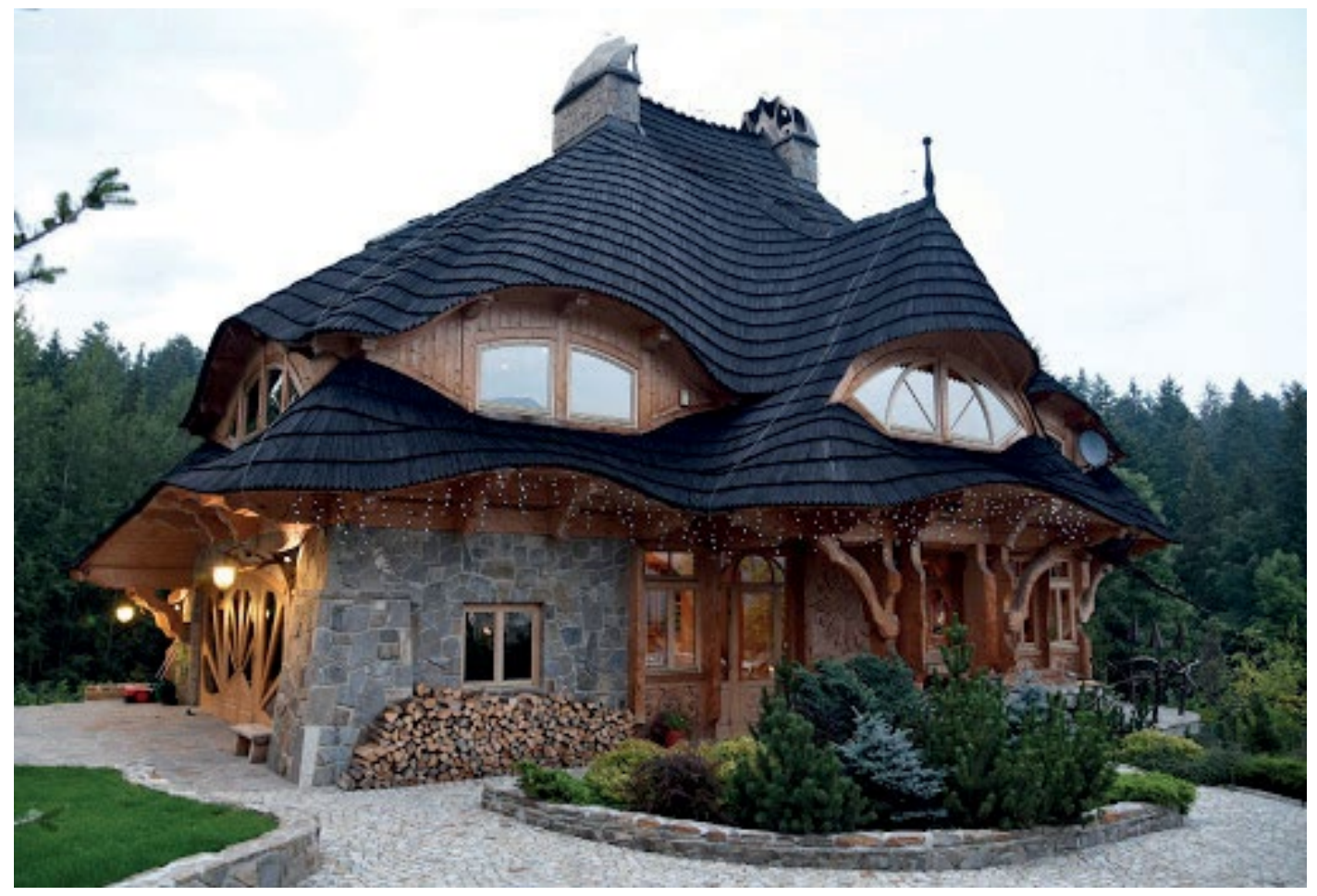

3. Dom na polanie Sywarna, arch. Sebastian Pitoń.

Fot. fachowydekarz.pl/sebastian-piton-goralski-gaudi [dostęp 20 X 2020]

znajdowały poparcia w estetyce

Witkiewicza, który podkreślał, że „każdy

styl o tyle tylko może być stylem, o ile działa pewną ograniczoną ilością form, może być tu naruszony przez komplikowanie form sztuki ludowej" ${ }^{27}$. W podobnym duchu utrzymane zostały inne projekty Sebastiana Pitonia, by wspomnieć tylko willę Kominiarski Wierch, karczmę Klepisko nad Zalewem Zegrzyńskim czy dom jednorodzinny z $2002 \mathrm{r}$. W ostatnim projekcie, poza opływowym kształtem dachu oraz wyszukanym kątem nachylenia okien dolnej kondygnacji, ważnym punktem o charakterze czysto dekoracyjnym stał się ogromny komin, będący częścią elewacji bocznej. Połączeniu przeciwstawnych wartości sprzeciwiał się również Witkiewicz - „jak człowiek nie może mieć jednocześnie nosa zadartego i garbatego, tak samo styl nie może jednocześnie działać łukiem ostrym i obłąkiem stanowiącym półkole" ${ }^{28}$. Biorąc pod uwagę liczne modyfikacje formalne oraz mnogość widocznych źródeł inspiracji, trudno oprzeć się wrażeniu, że w przypadku tej grupy projektów ma się do czynienia z zakopiańskim eklektyzmem, a nie z nowym stylem zakopiańskim. Pierwowzór, z którego czerpał chata góralska - stał się bowiem jedynie pretekstem do stylowych peregrynacji, znacząco oddalających się estetycznie od zakopiańskiej kolebki. Dla Witkiewicza to właśnie najprostsze budownictwo było nośnikiem najgłębszych wartości estetycznych, które rozwinął i kultywował. Uniwersalizmu i wartości tejże architektury upatrywał w jej prostocie, pisząc: „sam szkielet budowy, to pudło, w którym się chowa człowiek, ta część każdej rzeczy, która służy do celów praktycznych, jest równie prawie prosta i niezłożona, jak w każdej innej chacie. Cztery ściany, dwa szczyty, dwie pochyłe płaszczyzny dachu z małym zboczeniem od symetrii na jedną stronę, pod którą mieszczą się dodatkowe izby - oto cała chałupa"29.

27 S. Witkiewicz, dz. cyt., s. 281.

28 Tamże, s. 264.

29 Tamże, s. 256. 
Rozważając możliwość odrodzenia się stylu zakopiańskiego, trzeba wziąć pod uwagę jeszcze jedną rzecz, która znacząco wpływa na percepcję nowo powstających obiektów. Jest nią symbiotyczna relacja architektury i wyposażenia wnętrz, o której Witkiewicz pisał: „to przenikanie się wzajemne form rozmaitego użytku, jeżeli jest logiczne i zgodne z pierwotną wytwarzającą potrzebą, coraz bardziej skrzepia i ustala cechy stylowe" ${ }^{30}$. Omawiając styl zakopiański, nie sposób więc uniknąć odniesień do klasycznej syntezy sztuk w ujęciu Karla F. Trahndorffa, która zauważalna była już przy realizacji willi Koliba ${ }^{31}$, a która stała się synonimem w pełni zrealizowanych założeń estetyki witkiewiczowskiej. Pomimo bardzo dalekiej od pierwowzoru formy architektonicznej, Sebastian Pitoń jako jeden z nielicznych projektantów, co warto podkreślić, wykazuje konsekwencję w projektowaniu wnętrz budynków. Ornamentyka oraz organiczne kształty, będące wypracowanym przez niego stylem, znajdują odbicie w kształcie ścian działowych oraz dekoracyjnych pracach snycerskich. Na poziomie relacji budynek-wnętrze stanowi to o pewnym zwrocie w stronę idei Gesamtkunstwerk, która była realizowana przez artystów stylu zakopiańskiego.

Analizując liczne przykłady nowego stylu zakopiańskiego, warto przywołać dwa projekty, które znacząco różnią się od omawianych wcześniej realizacji. Pierwszym z nich jest dom w Burowie ${ }^{32}$, który oparty został o zgoła inny model inspiracji spuścizną architektoniczną

30 Tamże, s. 275.

31 T. Jabłońska, Stanisława Witkiewicza styl zakopiański. The Zakopane Style of Stanisław Witkiewicz, Lesko 2008, s. 38.

32 Dom w Burowie został w 2010 r. odznaczony Nagrodą Województwa Małopolskiego im. Stanisława Witkiewicza, www.witkiewicz.malopolskanagroda.pl/ index.php/edycja-2010/dom-w-burowie [dostęp $20 \mathrm{X}$ 2020].
Stanisława Witkiewicza. Położony na terenie Jurajskiego Parku Krajobrazowego obiekt, wzniesiony w 2009 r., został zaprojektowany przez krakowskie studio architektoniczne Wizja, którego dyrektorem jest Stanisław Deńko (il. 4). Bryła budynku została osadzona na planie prostokąta i nakryta dwuspadowym dachem, który jednak nie przesłania jej w całości, ukazując wysunięty fragment elewacji frontowej, nad którym umiejscowiono duży, prostokątny taras. Również w elewacji tylnej oraz bocznych wysunięto obrys parteru, by stworzyć przestrzeń balkonową, która nie jest objęta zasięgiem dachu. Na uwagę zasługuje wprowadzenie panoramicznych okien, integrujących wnętrza z otaczającym krajobrazem. Niezwykle sugestywnym nawiązaniem do architektury stylu zakopiańskiego jest wspomniany już dwuspadowy dach, który dodaje budowli wertykalizmu i dynamiki, tak charakterystycznych dla willi Witkiewicza. Jeśli przyjmie się, że „styl jest to tworzenie z pewnego ograniczonego

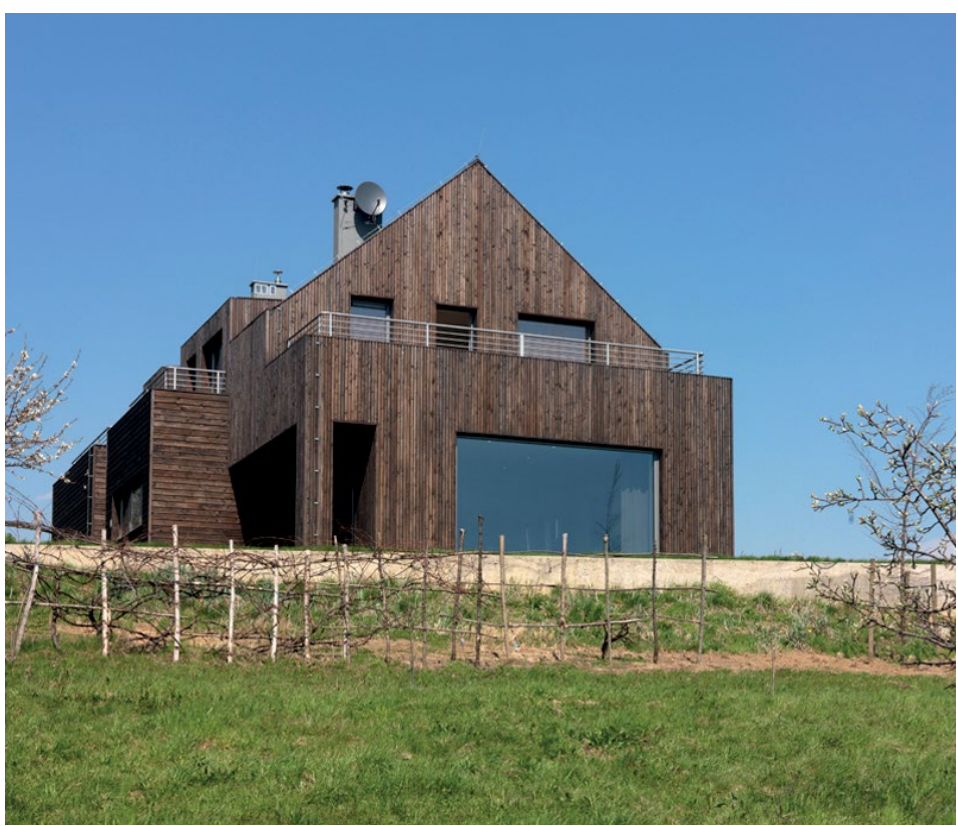

4. Dom w Burowie, Biuro architektoniczne Wizja. Fot. W. Kryński, www.wizja.krakow.pl/pl/projects/23 [dostęp $20 \mathrm{X}$ 2020] 
materiału formy, z wykluczeniem całej niezliczonej masy form odmiennych. Styl jest zacieśnieniem, zamknięciem się w pewnych granicach motywów twórczych i rozwijaniem się organicznym pewnych, zawsze jednakich pierwiastków"33, to można stwierdzić, iż redukcja formalna wypracowywana od lat 30., nosi znamiona ewolucji stylowej, czerpiącej selektywnie z dokonań pierwowzoru. Drugi przykład stanowi projekt Emil 2.0 - przebudowa domu z początku XX w. autorstwa studia architektonicznego Karpiel i Steindel (elewacja) oraz Wojciecha Gawinowskiego ze studia projektowego VOSTOK Design (wnętrza) ${ }^{34}$. Prosty dom na planie litery L, o dwuspadowym dachu, posłużył jako szkielet konstrukcyjny gruntownej przebudowy. Otwarty plan parteru i duże okna będące reminiscencją stylu loftowego zestawiono z poddaszem, które dzięki odsłoniętej drewnianej więźbie dachowej z jętkami oraz minimalistyczną ornamentyką w obrębie krokwi jest przykładem współczesnej adaptacji dawnych wzorów. Stanowi to o recepcji poglądów Witkiewicza, które u podstaw stawiały walory budowlane projektów - „zasadniczą cechą stylu zakopiańskiego jest konstrukcyjność - jest jawność więźby i dążność do jej podkreślenia za pomocą ornamentyki" ${ }^{35}$. Nowoczesna bryła domu zestawiona $\mathrm{z}$ dwuspadowym dachem, o trójkątnym oknie (wpisanym w miejsce klasycznego występowania detali snycerskich na szczytach chałup podhalańskich oraz budowli w stylu zakopiańskim) ukazuje dążenie do redukcji formalnej przy zachowaniu odwołań stylowych (il. 5). Elementy dekoracyjne zastąpiono utylitarnymi rozwiązaniami, które umożliwiają adaptację poddasza do celów mieszkalnych. Oba przykłady domów świadczą

33 s. Witkiewicz, dz. cyt., s. 264.

34 www.vstk.eu/przebudowa-domu-jednorodzinnego [dostęp 20 X 2020].

35 S. Witkiewicz, dz. cyt., s. 286. o odradzaniu się estetyki budownictwa regionalnego, które jednak nie zrywa z wypracowanymi dokonaniami modernizmu, a stanowi jego organiczną ewolucję w myśl teorii Charlesa Dowa o odradzaniu się trendów.

Na kanwie przytoczonych przykładów problem nowego stylu zakopiańskiego odsłonił kilka kwestii, które mogą budzić wątpliwości. Analizując budowle powstające w XXI w., zdecydowanie można dostrzec szereg inspiracji środowiskiem artystycznym Zakopanego początku ubiegłego wieku, które jednak oparte są zazwyczaj na eklektycznym łączeniu elementów kojarzonych ze stylem zakopiańskim w kulturze popularnej. Powrócono do form spadzistych dachów, zaimplementowano prace snycerskie oraz drewno i kamień - jako elementy konstrukcyjne lub dekoracyjną okładzinę elewacji. Choć ewidentnie widoczne są próby nawiązania estetycznego dialogu z przeszłością, to jednak odwołania te najczęściej stanowią jedynie zewnętrzną powłokę, nie wywodzą się bowiem ze zrozumienia idei Stanisława Witkiewicza, które leżały u podstaw jego prac. Na tym poziomie trudno mówić o odrodzeniu stylu, które zakłada zrozumienie i przetransponowanie wzorów dawnych do współczesnej architektury. Obecnie współistniejące rodzaje adaptacji klasycznego stylu zakopiańskiego oscylują między wernakularyzmem rewiwalistycznym i imitacyjnym, co nie daje przesłanek, by mówić o odrodzeniu stylowym. Należy dodać, że rewiwalizm zakłada również popularyzację motywów i ich geograficzne rozpowszechnienie, co w tym przypadku nie jest zauważalne.

Pozostaje jeszcze kwestia ukonstytuowania się nowej jakości estetycznej w architekturze, która może, choć nie musi, czerpać ze spuścizny Stanisława Witkiewicza. Jeśli tytułowy nowy styl zakopiański miałby odnosić się do słownikowej definicji „zespołu cech charakterystycznych dla sztuki 


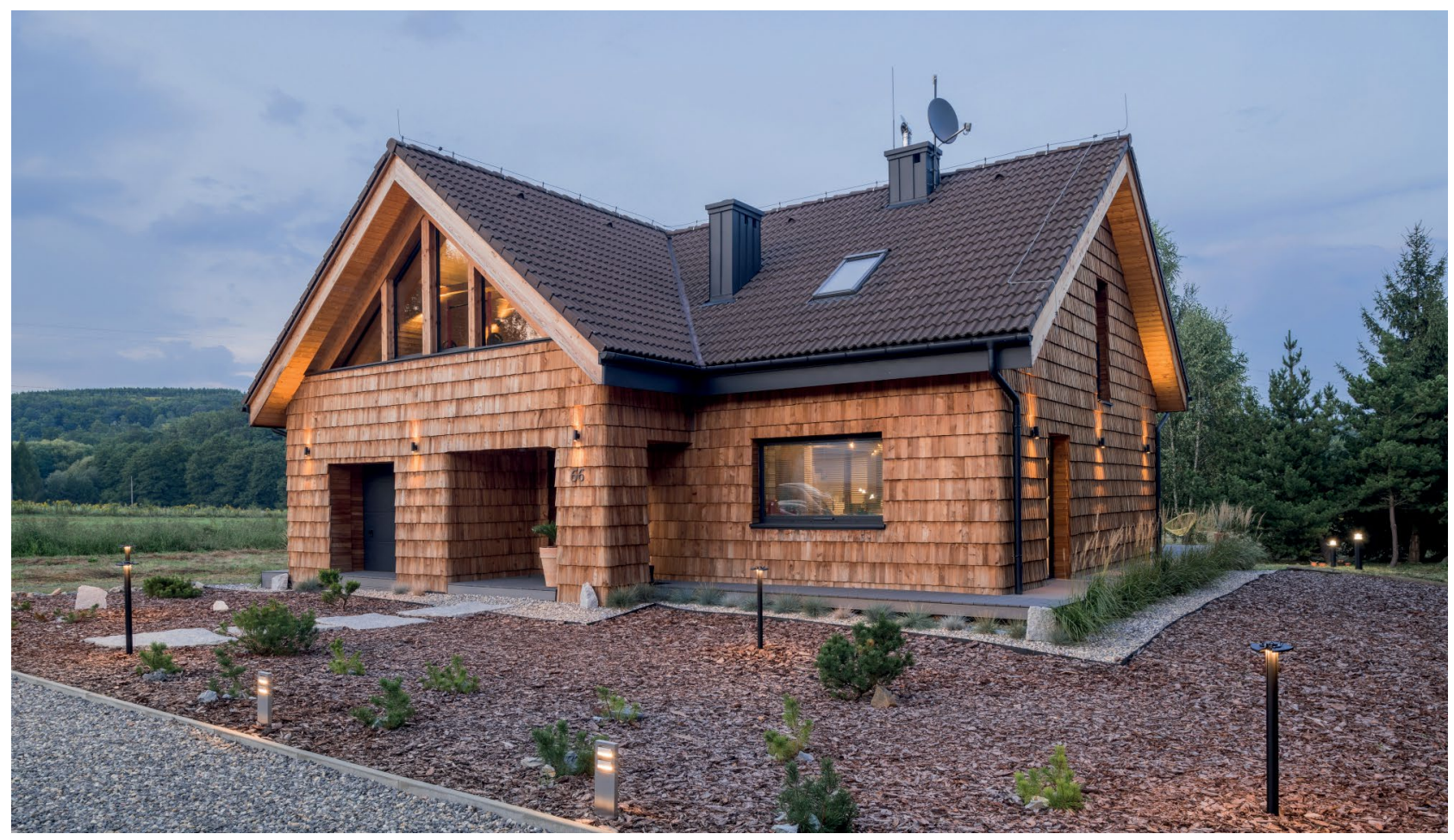

5. Dom Emil 2.0, Biuro architektoniczne Karpiel i Steindel oraz Studio projektowe VOSTOK Design. Fot. P. Ulatowski, www.essystem.pl/realizacje/186;emil-house-2o [dostęp 20 X 2020]

jakiejś epoki, jakiegoś regionu lub twórcy" ${ }^{36}$, należałoby zwrócić się ku kategorii lokatywnej. Wówczas jednak powstające na terenie Zakopanego budowle winny nosić znamiona pewnej konwencji architektonicznej, którą cechowałaby spójność i jednorodność formalna. Omawiane budowle w tym ujęciu nie stanowią więc kompilacji, którą można uznać za koherentną w stopniu wystarczającym, by świadczyła o wytworzeniu się nowego stylu budownictwa charakterystycznego dla Zakopanego i jego okolic.

Konkludując, pluralizm formalny przywołanych przykładów oraz siatka pojęciowa, którą zastosowano do ich analizy, świadczą niezbicie o wciąż żywych tradycjach stylu Stanisława Witkiewicza oraz sile jego oddziaływania w ostatnim stuleciu. Należy jednak podkreślić, że ich recepcja pozostaje bardzo powierzchowna. Świadczy to niezbicie o popkulturowej bytności

36 Styl, w: Słownik języka polskiego PWN, online: www. sjp.pwn.pl/sjp/styl;2576404.html [dostęp 4 X 2020]. szeroko pojętej zakopiańszczyzny, której popularność nie znajduje odzwierciedlenia w dogłębnym zrozumieniu jej fundamentalnych idei. Świadomość historyczna i estetyczna wypływająca z poszanowania lokalnych tradycji ustąpiła miejsca hybrydzie stylowej, której nie sposób nadać miana nowego stylu zakopiańskiego w rozumieniu głębokiej relacji z klasycznym pierwowzorem. Do miana nowego stylu zakopiańskiego mogą jednak w przyszłości pretendować projekty (np. biur architektonicznych Karpiel i Steindel czy Wizja), które tradycje Stanisława Witkiewicza traktują jako punkt wyjścia dla twórczej analizy przeszłości, przejawiającej się jako subtelne nawiązanie, a nie imitacja pierwowzoru. Czy tak się stanie, zweryfikuje popularność rewiwalizmu tradycji podhalańskich, który łączy dokonania modernizmu z historycznymi wartościami rodzimego budownictwa. 
STRESZCZENIE

ARCHITEKTURA NOWEGO STYLU

ZAKOPIAŃSKIEGO. ODRODZENIE

STYLOWE CZY POPKULTUROWY KICZ

I HISTORYCZNE NIEZROZUMIENIE?

Tekst porusza kwestie współczesnego budownictwa inspirowanego stylem zakopiańskim, szukając odpowiedzi na pytanie, czy wykazuje ono właściwe cechy, pozwalające określić je mianem rewiwalizmu historycznych wzorów. Wychodząc od założeń Stanisława Witkiewicza oraz teorii architektonicznego odrodzenia i neowernakularyzmu, artykuł przybliża i analizuje przykłady budowli tzw. nowego stylu zakopiańskiego. Komparatystyka obiektów i teorii estetycznych Witkiewicza w zestawieniu z rozszerzonymi definicjami wernakularyzmu stanowi trzon rozważań o możliwej próbie usytuowania rozwijających się obecnie tendencji stylowych na mapie architektury czerpiącej z dziedzictwa przeszłości. Na podstawie reprezentatywnych przykładów architektury powstałej po roku 2000 poddaje analizie słuszność popkulturowo ukonstytuowanego terminu nowy styl zakopiański.

\section{SŁOWA KLUCZOWE}

architektura, styl zakopiański, wernakularyzm, odrodzenie stylowe, neo-styl, estetyka nowego stylu zakopiańskiego

\section{BIBLIOGRAFIA}

Angutek Dorota, Folkloryzm i postfolkloryzm jako etnologiczna alternatywa terminologiczna obok wernakularyzmu i neowernakularyzmu, w: Wernakularyzm i neowernakularyzm w sztuce, literaturze i myśli o sztuce, red. Elżbieta Kal, Słupsk 2019, s. 57-67.

\section{SUMMARY}

ARCHITECTURE OF THE NEW ZAKOPANE

STYLE. STYLE REVIVAL OR POP-

CULTURAL KITSCH AND HISTORICAL MISUNDERSTANDING?

The text addresses the questions of contemporary architecture inspired by the Zakopane Style, examining whether or not they present the appropriate features that would predispose them to be described as the revivalism of historical patterns. Beginning with the aesthetic writings of Stanisław Witkiewicz and the theory of architectural revival and neo-vernacularism, the article introduces and analyzes examples of the socalled New Zakopane Style. The comparison of selected buildings with Witkiewicz's aesthetic theories, in combination with extended definitions of vernacularism, is the core of considerations about an attempt to situate the currently developing trends on the map of architectural styles drawing from the late 19th century heritage. On the basis of representative examples of architecture created after 2000 , the text aims to analyze the validity of the pop-culturally constituted term of the New Zakopane Style.

\section{KEYWORDS}

architecture, the Zakopane style, vernacularism, style revival, neo-style, aesthetics of the new Zakopane style

Biernot Teresa, Budynki witkiewiczowskie w Zakopanem. Materiały z badań inwentaryzacyjno-studialnych obiektów historycznych, Gliwice 2010.

Bukowska-Floreńska Irena, Kultury regionalne w społeczeństwach nowoczesnych. Problemy i propozycje badawcze, „Studia Etnologiczne i Antropologiczne", t. 2, 1999, s. 15-22. 
Cuijpers Robert, Eummelen Myrthe, van Groesen B.H.J., Kohlmann J.W.M., van der Vleugel B.R.J., Zondag M., Redefining revival: a systematic review on vernacular and non-place-bound revival, wystąpienie podczas konferencji Living Cities 5 At: Eindhoven, Holandia, tekst oraz wyniki badań udostępnione za pośrednictwem ResearchGate, www.researchgate.net/publication/326462248 [dostęp $4 \mathrm{X}$ 2020].

Czechowicz Marcin, Nowy styl zakopiański, „Murator”, wyd. online 30 XI 2017, https://architektura.muratorplus.pl/ krytyka/nowy-styl-zakopianski-fotoreportaz-marcina-czechowicza_8159.html [dostęp 24 IX 2020]. Gazda Lucjan, Górski Marcin, Skiba Katarzyna, Analiza możliwości adaptacji drewnianego obiektu rekreacyjnego w funkcjonalny obiekt mieszkalny z zachowaniem rozwiązań i technologii wernakularnych, „Budownictwo i Architektura", t. 14, 2015, nr 4, s. $29-42$.

Jabłońska Teresa, Stanisława Witkiewicza styl zakopiański. The Zakopane Style of Stanisław Witkiewicz, Lesko 2008.

Kent Conrad, Prindle Dennis, Park Güell, New York 1993.

Kronowski Dariusz, Wpływ architektury neoregionalnej i nowoczesnej na kształtowanie myśli krakowskiej szkoły projektowania architektonicznego, „Teka Komisji Urbanistyki i Architektury O/PAN W Krakowie", t. 42, 2014, s. 85-129.
Kwiatkowski Krzysztof, Konfrontacja stylów narodowych imperiów ze stylami narodowymi terytoriów zależnych, „Przestrzeń, Urbanistyka, Architektura”, 2020, nr 1, s. 67-76.

Murzyn Michał, Wpływ turystyki masowej na dziedzictwo Zakopanego, „Turystyka Kulturowa", 2015, nr 10, s. 72-85.

Pycka Anna Małgorzata, Kreacje i poglądy Stanisława Witkiewicza na tle głosów epoki, Kraków 2010.

Rytel Grzegorz, Wernakularna, czyli jaka? Uwagi semantyczne na marginesie tematu konferencji, „Budownictwo i Architektura", t. 14, 2015, nr 3 , s. 143-149.

Scott George Gilbert, Remarks on Secular \& Domestic Architecture, Present \& Future, London 1858, reprint: Charleston 2012.

Sznapik Adrianna D., Tatrzańska Arkadia. Zakopane jako ośrodek artystyczno-intelektualny od około 1880 do 1914 roku, Warszawa 2009.

Tarnowski Józef, Styl alpejski w środkowej Europie i polska kontrakcja wobec niego - styl zakopiański, „Estetyka i Krytyka", 2012, nr 25 (2), s. 231-246.

Tarnowski Józef, Wernakularyzm i neowernakularyzm: zamiast wstępu, w: Wernakularyzm i neowernakularyzm w sztuce, literaturze i myśli o sztuce, red. Elżbieta Kal, Słupsk 2019, s. 9-34.

Witkiewicz Stanisław, Wybór pism estetycznych, red. Józef Tarnowski, Kraków 2009. 